\title{
Quantification of NADPH balance during adipogenesis
}

\author{
Ling Liư ${ }^{1 *}$, Supriya Shah², Jing Fan', Kathryn Wellen², Joshua Rabinowitz ${ }^{1}$ \\ From Metabolism, Diet and Disease 2014: Cancer and metabolism \\ Washington DC, USA. 28-30 May 2014
}

\section{Background}

NADPH provides reducing power for macromolecule synthesis and antioxidant defense. The pathways used to make NADPH under different physiological circumstances remain unclear. In growing cells, much NADPH production is coupled to nucleotide synthesis via the oxidative pentose phosphate and folate pathways. Here we examine, using isotope tracers and flux analysis, NADPH production routes in adipocytes.

\section{Materials and methods}

Adipocytes were harvested at different time points during differentiation. To estimate NADPH demand for the reductive steps of fatty acid synthesis, lipids were isolated, saponified into fatty acids and analyzed by liquid chromatography-mass spectrometry (LC-MS). Direct measurement of NADPH deuterium labeling was applied to quantitate NADPH fluxes from the oxPPP and folate pathway [1,2]. Tracing of passage of ${ }^{13} \mathrm{C}$ from glutamine into pyruvate/lactate was applied to quantitate malic enzyme flux.

\section{Results}

Cells synthesized $30 \mathrm{nM} /$ day/uL packed cell volume of acetyl units into fatty acids. To support this, a minimum of $60 \mathrm{nM} \mathrm{NADPH/day/uL} \mathrm{cell} \mathrm{volume} \mathrm{is} \mathrm{needed.} \mathrm{The}$ pentose phosphate pathway and folate pathways contributed less than $30 \%$ of the total required NADPH. The ${ }^{13} \mathrm{C}$-glutamine tracer analysis revealed that more than $5 \%$ of pyruvate came from malate, with the associated flux, if all through NADPH-dependent malic enzyme, capable of generating 300nM NADPH/ day/uL cell volume. Thus, malic enzyme flux is potentially sufficient to produce all of the required NADPH. To confirm its

'Lewis-Sigler Institute for Integrative Genomics and Department of Chemistry, Princeton University, Princeton, NJ, USA

Full list of author information is available at the end of the article role, we are working to ensure that the observed flux from malate to pyruvate is via NADPH-dependent malic enzyme as opposed to NADH-dependent malic enzyme or PEPCK-pyruvate kinase.

\section{Conclusion}

Malic enzyme appears to be the main NADPH source in adipocytes.

\section{Authors' details}

${ }^{1}$ Lewis-Sigler Institute for Integrative Genomics and Department of Chemistry, Princeton University, Princeton, NJ, USA. ²Department of Cancer Biology, University of Pennsylvania Perelman School of Medicine,

Philadelphia, PA, USA.

Published: 28 May 2014

\section{References}

1. Fan J, et al: Quantitative flux analysis reveals folate-dependent NADPH production. Nature 2014, accepted.

2. Lu W, et al: Metabolomic analysis via reversed-phase ion-pairing liquid chromatography coupled to a stand alone orbitrap mass spectrometer. Anal Chem 2010, 82:3212-3221.

doi:10.1186/2049-3002-2-S1-P40

Cite this article as: Liu et al.: Quantification of NADPH balance during adipogenesis. Cancer \& Metabolism 2014 2(Suppl 1):P40.

Submit your next manuscript to BioMed Central and take full advantage of:

- Convenient online submission

- Thorough peer review

- No space constraints or color figure charges

- Immediate publication on acceptance

- Inclusion in PubMed, CAS, Scopus and Google Scholar

- Research which is freely available for redistribution
C Biomed Central

(c) 2014 Liu et al; licensee BioMed Central Ltd. This is an Open Access article distributed under the terms of the Creative Commons Attribution License (http://creativecommons.org/licenses/by/4.0), which permits unrestricted use, distribution, and reproduction in any medium, provided the original work is properly cited. The Creative Commons Public Domain Dedication waiver (http://creativecommons.org/publicdomain/zero/1.0/) applies to the data made available in this article, unless otherwise stated. 